\title{
XXIV. On the theory of the gaseous voltaic battery
}

\section{C.F. Schœnbein}

To cite this article: C.F. Schœnbein (1843) XXIV. On the theory of the gaseous voltaic battery , Philosophical Magazine Series 3, 22:144, 165-166, DOI: 10.1080/14786444308636343

To link to this article: http://dx.doi.org/10.1080/14786444308636343

册 Published online: 01 Jun 2009.

Submit your article to this journal $\pi$

Џ Article views: 7

Q View related articles $\sqsubset$ 
strict geometrical kind, and to those floating vapours we could hardly assign anything like symmetrical results,-_-guided, also, by the analogy of cooling bodies, which lose part of their heat through radiation, and part through the current action of the air, and part through the conducting power of their supports, I have been led to take the view of the phænomena in question which I have set forth.

University, New York, Dec. 5, 1842.

XXIV. On the Theory of the Gaseous Voltaic Battery. By C. F. Schonisein, Professor of Chemistry in the University of Bâsle.

Mr dear Sir,

$$
\text { To R. Taylor, Esq. }
$$

T $T$ was with no small degree of interest that I perused the 1 other day Mr. Grove's communication [Phil. Mag. S. 3. vol. xxi.p. 417], containing a description both of a gaseous voltaic battery, and of some experiments made with that arrangement. The results obtained by that distinguished philosopher are, indeed, such as will certainly draw upon them the attention of all scientific men who occupy themselves with voltaic researches. Having myself made some investigations concerning a similar subject, and ascertained a series of facts which, in my opinion, are closely . connected with Professor Grove's beautiful experiments, - and a good deal of scientific interest being attached to the matter in question-I take the liberty to direct your attention to the contents of a paper of mine which was published first in the Transactions of the Swiss Association, 184I, and afterwards in Poggendorff's Annalen, 1842, No. 5, under the title, "On the Voltaic Polarization of Solid and Fluid Bodies."

As some of the questions and suggestions stated in $\mathrm{Mr}$. Grove's last paper have already been answered and appreciated, and one or two material points immediately bearing upon the recent researches of that ingenious and skilful experimenter are fully discussed in the memoir alluded to, it might, perhaps, interest those English philosophers who are not in the habit of reading German periodicals, to see in your excellent Magazine a translation of my paper, or some abstracts from it.

Before closing my letter, permit me to say a few words in reference to the voltaic part which, in my humble opinion, oxygen acts in the novel gaseous battery of Mr. Grove. According to my experiments, as stated in the paper beforementioned, an aqueous solution of hydrogen being voltaically 
combined with chemically pure water, and the circuit thus formed completed by platinum, produces a current which passes from the solution to the water, though no trace of free oxygen should happen to be contained in either fluid. By letting pass either the latter gas or atmospheric air into the solution of hydrogen, I could not sensibly increase the current produced by the arrangement, from which negative result I thought I was entitled to draw the conclusion, that the current being generated under those circumstances cannot be due to the combination of free hydrogen with isolated oxygen: an inference which may also be drawn from Mr. Grove's arrangement itself, for the oxygen being contained in one tube cannot be supposed to combine with the hydrogen inclosed in another tube.

An aqueous solution of oxygen being voltaically associated with pure water is not capable of exciting a sensible current if the circuit happens to be completed by means of platinum, a fact from which it seems likewise to follow that in Grove's novel pile oxygen does not immediately contribute to the production of its current.

But if the current of that arrangement be, nevertheless, augmented by having the alternate glass-tubes filled with oxygen, I am inclined to ascribe that effect to the depolarizing action exerted by oxygen upon the negative platinum electrodes which are inserted in the tubes containing that gaseous body. From obvious reasons that action must be greatly facilitated and accelerated by the well-known power of platinum to favour the chemical union of hydrogen with oxygen.

It is, however, very likely that in the oxygen tubes, besides the depolarizing action, there is some other electromotive force called into play; but having treated of this subject in a paper ("On the electrolytical power of a simple pile") which, I presume, was read before the British Association at Manchester, and published in the last Number of De la Rive's Archives, I will not enter into more details on that subject, but take the liberty of referring to the memoir itself.

$$
\text { I remain, my dear Sir, }
$$

$$
\text { Yours very truly, }
$$

Bâsle, Dec. 28, 1842.

C. F. Schanbein.

P.S. Experimenters who are desirous of pursuing $\mathrm{Mr}$. Grove's late researches, will find the effects of the gaseous pile greatly enhanced by making use of chlorine gas instead of oxygen; at least the experiments I made on the voltaic properties of chlorine and bromine, some time ago, lead to such a conclusion. 